\title{
Atık Termoplastiklerin Geri Dönüşüm Sürecinde Makine Odaklı Risk Değerlendirmesi
}

\author{
Machine-Focused Risk Assessment in the Recycling of Waste Thermoplastics
}

\author{
Ufuk Fatih KÜçÜKALi (i) , Necati YALMAN
}

\begin{abstract}
ÖZET
Dünyada endüstrinin gelişmesiyle birlikte, genel olarak "plastikler" olarak nitelendirilen ve fosil yakıtlardan üretilen, polimerlerin (termoplastik, termoset, elastomer) kullanım alanları çoğalmıştır. Bu durumu etkileyen en önemli faktör ise diğer hammaddelerden (metal, demir, alüminyum, bakır, çinko, ağaç vb.) yapılan ürünlere kıyasla plastik mamullerin daha kolay erişebilir olmalarıdır. Türkiye'de polimerler; otomotiv, inşaat, tarım, temizlik ve kozmetik, sağlık sektörü gibi geniş bir yelpaze kullanılmaktadır.

Türkiye'de plastik geri dönüşüm sektöründe lisanslı işletme sayısının bin civarında olduğu ve bu işletmelerde en az 350 bin kişinin istihdam edildiği bilinmektedir. Yüksek üretim kapasitesine sahip olan bu sektör gerek hurda atık plastik ithalatı gerekse dönüştürdüğü malzemelerin ihracatı ile Türkiye ekonomisinde giderek büyüyen bir öneme sahip stratejik bir sektör konumundadır.

Bu çalışmada risk değerlendirmeleri; Ön Tehlike Analizi (PHA) ve Tehlike Derecelendirme Numarası Sistemi (HRNS) risk analizi metotlarıyla karşılaştırmalı olarak yapılmıştır. Ayrıca Makine Odaklı Risk Değerlendirmelerinde (MORD) en önemli sırada olan, Emniyet Standardı TS EN ISO 12100: 2010, ve elektriksel tedbirlerle ilgili TS EN 13849 kapsamında değerlendirmeye çalışılmıştr.

Çalışma uygulama ile desteklenmiş, risk değerlendirme adımlarının ortaya konması ile özellikle iş sağlığı ve güvenliği (İSG) sektöründe önemli bir eksikliğin giderilmesi ve İSG uzmanlarının da başvuru kaynağı olarak kullanabileceği bir çalışma yapılmaya çalışılmıştır.
\end{abstract}

Anahtar Kelimeler: Geri Dönüşüm, Risk Analizi, Standartlar, Blok Tipi Kırma Makinesi

\section{ABSTRACT}

With the development of industry in our world, the usage areas of polymers (thermoplastic, thermoset, elastomer) which are generally defined as plastics and produced from fossil fuels have increased. The most important factor affecting this situation is that plastic mauls are more easily accessible than products made from other raw materials (metal, iron, aluminum, copper, zinc, wood, etc.). Polymers are used in a wide range of sectors such as automotive, construction, agriculture, cleaning, cosmetics, and health in Turkey.

In Turkey, where around a thousand of the number of licensed company in the plastics recycling sector and in this company it is known that at least 350 thousand people are employed. Having a high production capacity in this sector should scrap materials that convert waste plastic imports both in Turkey's economy has a growing importance of the export sector is a strategic location.

In this study, risk assessments; Preliminary Hazard Analysis (PHA) and Hazard Rating Number System (HRNS) were performed in comparison with risk analysis methods. In addition, it has been tried to evaluate Safety Standard TS EN ISO 12100: 2010, which is the most important in Machine Oriented Risk Assessments (MORD), and TS EN 13849 related to electrical measures.

The study was supported by implementation, and by revealing the risk assessment steps, a study was tried to eliminate a significant deficiency especially in the occupational health and safety sector and a work that OHS experts could use as reference.

Keywords: Recycling, Risk Analysis, Standards, Block Type Crushing Machine

Ufuk Fatih KÜçÜKALi I ufukfatih@yahoo.com

İstanbul Aydın Üniversitesi, Mimarlık ve Tasarım Fakültesi, İstanbul, Türkiye

Istanbul Aydın University, Architecture and Design Faculty, İstanbul, Turkey

Necati YALMAN I necati.yalman@hotmail.com

İstanbul Aydın Üniversitesi, Mühendislik Fakültesi, İstanbul, Türkiye

Istanbul Aydın University, Faculty of Engineering, Istanbul, Turkey 


\section{GİRIŞ}

Dünyada 1907 yılından başlayan plastik mamul üretimi insanların hayatına kolaylık getirmiştir [1,2]. Bu durumu etkileyen en önemli faktör ise diğer hammaddelerden (metal, ağaç vb.) yapılan mamullere kıyasla plastik mamullerin daha kolay erişilebilir olmalarıdır[3]. Ayrıca mamul maliyetlerinin düşmesi makine sektöründe üretilen endüstriyel makineler sayesinde mümkün hale gelmiştir. Günümüzde plastiğin aşırı tüketimi ve geri dönüştürme oranlarının düşüklüğü çevre sorunu haline gelmiş durumdadır[4] . Tüketim ihtiyaçlarını plastik mamuller üzerinden bu hızla karşılanmaya devam edilir ve geri dönüştürme oranları bugünkü seviyede kalacak olursa bilim insanlarına göre 2050 yılında denizlerde balıktan çok plastik olacağı belirtilmekte$\operatorname{dir}[5]$.

Atık plastiklerin çevreye negatif etkileri her kesim tarafından fark edilmiş ve çözüm yolları taraflarca alınmaya devam edilmektedir[6]. Yakın tarihte üzerinde değişiklik yapılan 9/8/1983 tarihli 2872 sayılı çevre kanunun bazı maddelerinde 9/11/2018 tarihli 7153 sayılı kanunla değiştirilmiştir. Marketlerde tek kullanımlık plastik poşetler paralı hale getirilmiş ve çevre kirliliği önlenmesi açısından faydalı bir başlangıç olmuştur. Bu gelişmeler çerçevesinde “atık plastik geri dönüşüm sektörü” hem olumlu etkilenmiş, hem de kendisini sorumluluk altında hissetmektedir. Makine teknolojileri atık plastiği geri dönüştürüp ekonomik değer haline getiren süreçleri içerir. Bu ekonomik değer kazanma, plastik geri dönüşüm sektörünü ve bu sektörde kullanılan makine aksamlarının çeşitlenmesine kapasitelerinin artmasına neden olmuştur. Atık Plastik kırıcılar “Atık Plastik Geri Dönüşüm” sürecinin en tehlikeli makinesi olduğu risk skorlarında görülmektedir. Değişik kapasitelerde ve gövde genişlikleri olan (200 -1500) mm sistemleri mevcuttur. Atık plastiklerin depolama ve nakliye sorunu- nu ortadan kaldıran makine konumu olup plastiğin üretiminin yapıldığı her işyerinde olması zorunlu bir makinedir. $\mathrm{Bu}$ makineler işletmelerde depolama alanlarında tasarruf sağlanmasına olanak tanırlar.

\section{A. Türkiye’de Plastik Mamul Sektörü}

Türkiye'de plastik mamul üretimi 2018'in ilk altı ayında 5 milyon 52 bin ton olarak kayıtlara geçmiştir. Bu üretimin ortaya koyduğu ekonomik değer 19 milyar 375 milyon \$ civarındadır. Bu plastik mamul üretimi 2019'un ilk altı aylık döneminde 4 milyon 477 bin tona ve tutar olarak da 15 milyar 953 milyon \$ a inmiştir. Türkiye'de 2019'un ilk altı ayındaki plastik mamul üretimi 2018'in ilk altı ayına göre miktar bazında \% 11, değer bazında \% 18 azılmıştır (Tablo 1).

Tablo 1: Plastik mamul üretimi eș dönem kıyaslaması[7]

\begin{tabular}{cccccccc}
\hline & & & & & $\begin{array}{c}\text { \%Azalma } \\
\text { 2019/2018 }\end{array}$ & $\begin{array}{c}\text { \%Azalma } \\
\text { Tahmini }\end{array}$ \\
& $\mathbf{2 0 1 8 / 6}$ & $\mathbf{2 0 1 8}$ & $\mathbf{2 0 1 9 / 6}$ & $\mathbf{2 0 1 9 / T}$ & (Ay) & $\mathbf{2 0 1 9 / 2 0 1 8}$ \\
\hline 1000Ton & 5.052 & 9.144 & 4.477 & 8.955 & 11 & 2 \\
Milyon \$ & 19.375 & 34.289 & 15.953 & 31.907 & 18 & 7 \\
\hline
\end{tabular}

Plastik mamul üretimi 2019 yılı sonunda 2018 yılına göre miktar bazında \% 2, değer bazında \% 7 azalarak 8,96 milyon ton ve 31,9 milyar $\$$ a ineceği tahmin edilmektedir.

Grafik 1: Plastik mamul üretimi[7]

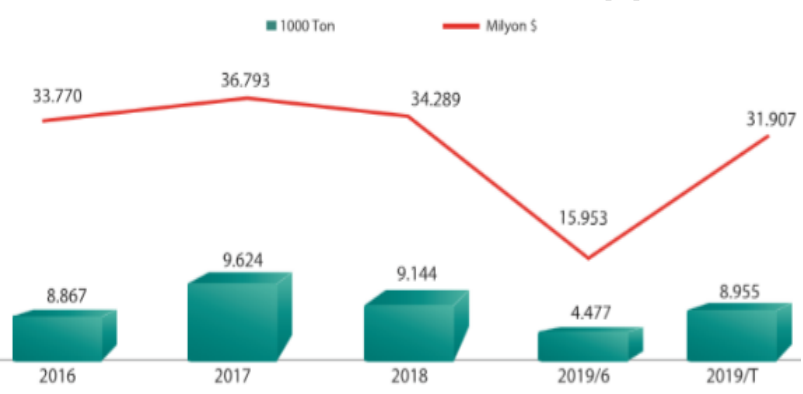

2019'un ilk atlı aylık döneminde 4,48 milyon ton toplamda mamul üretilmiştir. Bu üretimin yaklaşık 1 milyon791 bin tonu plastik ambalajdır (Tablo 2). Bunu 985 ton ile plastik inşaat malzemeleri takip etmektedir. 
Tablo 2: Alt sektörlere göre plastik mamul üretimi [7]

\begin{tabular}{cc}
\hline Alt Sektör & (1000 ton) \\
\hline Ambalaj & 1791 \\
Inşaat & 985 \\
Diğerleri & 627 \\
Beyaz Eşya & 448 \\
Tarım & 269 \\
Otomotiv & 179 \\
Tekstil & 179 \\
\hline
\end{tabular}

Türkiye'de plastik ambalaj sektöründe 1450 firma faaliyet göstermektedir. Yapılan malzeme bazındaki üretimlerin belirli bir birim üzerinden tarifi yapılmamaktadır. Sektördeki üretimin dağılımı ise \% 67'si fleksible plastik, \% 18’i tekstil plastik ve \% 15'i de sert plastik ambalaj malzemelerinden oluşmaktadır[7]. Ayrıca bu firmaların illere göre dağılımı (Tablo 3) incelendiğinde 871 firma ile İstanbul ilk sırada yer almaktadır.

Tablo 3: Plastik mamulleri üreticilerinin illere göre dağılımı[7]

\begin{tabular}{lcc}
\hline Şehir & Adet & $\%$ \\
\hline İstanbul & 871 & 61 \\
İzmir & 84 & 6 \\
Konya & 57 & 4 \\
Ankara & 51 & 4 \\
Bursa & 51 & 4 \\
Gaziantep & 42 & 3 \\
Kocaeli & 40 & 3 \\
Adana & 27 & 2 \\
Denizli & 23 & 2 \\
Mersin & 17 & 1 \\
Kayseri & 16 & 1 \\
Manisa & 15 & 1 \\
Samsun & 13 & 1 \\
Antalya & 11 & 1 \\
Diğer İler & 105 & 7 \\
\hline Sektör Toplamı & 1423 & 100 \\
\hline
\end{tabular}

Plastik Sektöründe 2014-2018 yıllarını kapsayan son 5 yıllık süreçte yıllık ortalama 892 milyon \$ makine yatırımı gerçekleştirilmiştir. Bu makinelerin dağılımına Tablo 4’de incelediğimizde $\% 37$ 'sini presler ve diğer makineler, \% 22 'sini enjeksiyon, \% 18 ekstrüzyon, \% 4 termoform, \% 2 'sini şişirme ve \% 17'de aksam ve parçalar oluşturmakta$\operatorname{dir}[7]$.
Tablo 4: Sektörde 2014-2018 döneminde makine yatırımları yüzdesel dağılımı[7]

\begin{tabular}{lc}
\hline Makine Adı & $\%$ \\
\hline Pres ve Diğer Makineler & 32 \\
Enjeksiyon & 22 \\
Ekstrüzyon & 18 \\
Termefrom & 4 \\
Şişirme & 2 \\
Aksam ve Parçalar & 17 \\
\hline
\end{tabular}

Plastik mamul üretimindeki bu daralma, paralelinde plastik işleme makineleri sektörüne negatif etkilemiştir. Plastik işleme makineleri sektörünün 2018' in ilk altı ayına göre 2019 ilk altı ayı değerlendirildiğinde üretim \% 20, ithalat $\% 48$, ihracat $\% 1$ ve yurt içi satışlar $\% 42$ azalmıştır. Bu eğilim devam eder ise $2018^{\prime}$ in ikinci altı ayına kıyasla 2019'un ikinci altı ayı tahminleri ise üretim \%17, ithalat $\% 45$, ihracatın $\% 20$,iç satışların $\% 34$ azalacağı yönünde$\operatorname{dir}[7]$.

Tablo 5: Plastik işleme makinelerinde arz ve talep 2018 ve 2019 eș dönem kıyaslaması[7]

\begin{tabular}{lcccccc}
\hline & $\mathbf{2 0 1 8 / 6}$ & $\mathbf{2 0 1 8}$ & $\mathbf{2 0 1 9 / 6}$ & $\mathbf{2 0 1 9 / T}$ & $\begin{array}{c}\text { \%Artış } \\
\text { 2019/2018 } \\
\text { (6Ay) }\end{array}$ & $\begin{array}{c}\text { \% Artış } \\
\text { Tahmini } \\
\mathbf{2 0 1 9 / 2 0 1 8}\end{array}$ \\
\hline Üretim & 286 & 553 & 229 & 457 & -20 & -17 \\
İthalat & 338 & 629 & 174 & 348 & -48 & -45 \\
İhracat & 98 & 242 & 97 & 194 & -1 & -20 \\
İç Satış & 526 & 940 & 306 & 611 & -42 & -35 \\
\hline
\end{tabular}

Plastik sektöründe makine ve teçhizatı yatırımı 2019 y1lında 306 milyon \$ gerçekleşmiş, bu daralma sürerse 2019 yilı sonu 611 milyon \$ 2018 yılına göre \% 35 gerileme olacağı tahmin edilmektedir.

Tablo 6: Plastik sektörünün makine ve teçhizat yatırımı[7]

\begin{tabular}{ccccc}
\multicolumn{5}{c}{ yatir1mi[7] } \\
\hline Yıl & $\mathbf{2 0 1 7}$ & $\mathbf{2 0 1 8}$ & $\mathbf{2 0 1 9 / 6}$ & 2019/T \\
\hline Milyon \$ & 932 & 940 & 306 & 611 \\
\hline
\end{tabular}

2019’un ilk aylık plastik sektörünün makine yatırımı 306 milyon \$ dır. Bu yatırımın \% 17 enjeksiyon, \%13 ekstrüzyon, \% 43’ü de presler ve diğer makineler ve \% 20 aksam ve parçalar oluşturmuştur. Toplam yatırımdan şişir- 
me makineleri $\% 3$ ve termoform $\% 4$ pay almışlardır.

Tablo 7: Plastik sektörünün yapmış olduğu makine ve teçhizat yatırımı(2019/6) [7]

\begin{tabular}{lc}
\hline Makine Adı & $\%$ \\
\hline Pres ve Diğer Makineler & 43 \\
Enjeksiyon & 17 \\
Ekstrüzyon & 13 \\
Termefrom & 4 \\
Şişirme & 3 \\
Aksam ve Parçalar & 20 \\
\hline
\end{tabular}

\section{B. Türkiye’de Plastik Geri Dönüşüm Sektörü}

Günümüzde dünyada yıllık plastik tüketimi 370 milyon tondur. 2050 yılında ise bu sayı 1 milyar ton olarak öngörülmektedir. Türkiye’de 6 ile 7 milyon geri dönüştürülebilecek atığın 5,5 milyon tonu gömülerek bertaraf edilmektedir. Plastik Geri Dönüşüm Sektörü, 2018 yılında 436 bin ton hurda ithal etmiş ve 116 milyon \$ ödemiştir. Ayrıca ihracatı yapılan bu faaliyetten 770 milyon \$ elde edilmiştir. Türkiye'de Plastik Geri Dönüşüm Sektöründe lisanslı işletme sayısı 1039 bu işletmelerde azami 350 bin kişi istihdam edilmektedir. Bugün itibariyle kapasite olarak 850 bin tona ulaşmıştır. 2030 yılında normal gidişat ile 4,3 milyon ton hedefte durmaktadır[7].

Geri dönüşüm geri kazanılacak malzemenin ekonomik değerinin yanında sürdürülebilir çevre açısından da önem arz etmektedir. Geri kazanımın ilgi alanı, geniş bir yelpaze içermektedir. Kabaca bakıldığında geri kazanımı olan; metal (demir, alüminyum, bakır, çinko, vb.), polimerler (termosetler, elastomerler, termoplastikler), kompozitler (elektronik atıklar, buzdolabı, televizyon, laptop, vb.), sıvı yağlar (motor ve kızarma) ve cam (ambalaj şişesi, araba camları, vb.) gibi malzemeler karşımıza çıkmaktadır. Kazanım süreci fiziksel ve kimyasal yöntemler kullanılarak elde edilir. Ayrıca geri kazanımdan enerji elde etmek için yakıt olarak kalorilik değeri $4000 \mathrm{kcal} / \mathrm{kg}$ olan alternatif yakıt ürünü, İSTAÇ Kemerburgaz tesislerinde elde edilmektedir. $\mathrm{Bu}$ alternatif yakıt çimento sanayinde petro-kok yerine kullanılabilmektedir.

$\mathrm{Bu}$ çalışmada polimerlerin bir kolu olan kullanım ömrünü tamamlamış termoplastiklerin geri kazanılmasın da kullanılan makinelerdeki tehlikeler analiz edilmiştir. Geri dönüşüm birbirini takip eden bir süreç uygulamasıdır. Kullanım ömrünü tamamlamış geri dönüştürüldüğünde ekonomik değeri olan plastik atıkların yada plastik ürün üretimi sırasında yolluk ve defolu ürünlerin tekrar ikincil hammadde olarak kazanılmasında Şekil 1'de görülen plastik kırma makinesi-yıkama havuzu-silindirik sıkma makinesi-agromel makinesi-granül çekme makinesi-kafadan kesme mekanizması-santrifüj makinesi-emme fan ve depolama haznesi gibi makine teçhizatı kullanılmaktadır.

Bu bölümde; atık plastik geri dönüşüm işi yapan işyerlerinde kullanılan makinelerin tanıtımı amaçlanmıştır. Atık plastiğin geri kazanılması, farklı tür makinelerin bir süreç içinde kullanılmasıyla mümkün olmaktadır. Doğru risk değerlendirmesi yapılabilmesi; kullanılan makinelerinin teknik bilgilerinin, çalıştırılma koşullarının, bakım ve kullanım şartlarının bilinmesine bağlıdır. Bu nedenle risk değerlendirmesini yapacak İSG uzmanın makinelerin teknik özelliklerini bilmesi büyük önem arz etmektedir. Makineler hem tekli (kırıcı olarak) hem bir süreç halinde kullanılmaktadırlar. Şekil 1' de atık plastik geri dönüşümü sürecinin on dört adet makine ve mekanizma ile 16 elektrik tahrik motoru, 8 adet redüktör, 6 aktarma organından meydan geldiği görülmektedir. Sistemde yer alan makine ve makine gruplarından kaynaklanan tehlikeler aşağıda; $\ddot{O}_{n}$ Tehlike Analizi (PHA) yöntemi ile tespit edilerek, Makine Odaklı Risk Değerlendirmesinde kullanılan; Tehlike Derecelendirme Numarası Sistemi (HRNS) ile tehlikeler proaktif yaklaşımla değerlendirilmiştir. Ayrıca var olan ve olabilecek tehlikelere yanlarında olay numaraları (Oi), Makine Odaklı Risk Değerlendirmesi (MORD) ve Ön Tehlike Analizi (PHA) kısaltılmaları kullanılmıştır. 
Atık termoplastiklerin geri kazanılma sürecini incelendiğinde sırasıyla aşağıda belirtilen aşamalardan geçmektedir. Bu duruma atık-ürün gitgeli denilmektedir.

1. Kullanım ömrünü tamamlamış atık termoplastikler toplama alanlarında cinsine (PP - Polipropilenen, PVS - polivinil klorür, PC, PS, HDPE, LDPE) göre ayrıştırılır,

2. Ayrışıııllan atık termoplastik suyu kırıcı makinesinde işlenebilir hacimde kırılarak çapak haline getirilir,

3. Plastik kırıcıda kirli olarak kırılan termoplastik çapak yıkama havuzunda çeşitli kimyasallar (klor, köpük sökücü, su, vb.) kullanılarak yüzdürme ve döndürme metodu ile yıkanarak temizlenir,

4. Temizlenmiş termoplastik çapak yıkama havuzundan taşıyıcı helezon vasıtasıyla silindirik sıkma makinesine aktarlır. Termoplastik çapak silindirik sıkma makinesinde sıkıştırma işleminden geçirilerek çapağın susuzlaşması sağlanır,

5. Silindirik sıkma makinesinden taşıyıcı helezon marifeti ile agromele aktarılan susuzlaştırılmış termoplastik çapak bu makinede şoklanarak kurutulur,

6. Kurutulmuş termoplastik çapak taşıyıcı helezon vasıtasıyla ekstüriderin huni olarak adlandırılan kısmına aktarılır. Ekstüriderin kovan ve mil mekanizmaları termoplastik çapağını eriyik hale getirerek kafadan kesme mekanizmasına gönderir. Termoplastik çapak kafadan kesme mekanizmasında tespih hacminde küçültülür,

7. Kafadan kesmenin mekanizmasında sıcak ve sünek yapıda olan termoplastik çapak su ile soğutma yapılır. Bu aşamada termoplastik çapağı granüle dönüşür. Granülün soğutması su ile yapılmasından dolayı santrafüj makinesi kullanılarak tekrar susuzlaştırma yapılır. Susuzlaştırılmış granül fan marifeti ile depolama silosuna gönderilir,

8. Depolama alanından cinsine göre ayrı ayrı depolanan granül enjeksiyon, şişirme ve bunlara benzer makinelerde kullanılmak üzere plastik mamul üreticilerine gönderilir.

Şekil 1: Geri dönüşüm sürecindeki makineler[8]

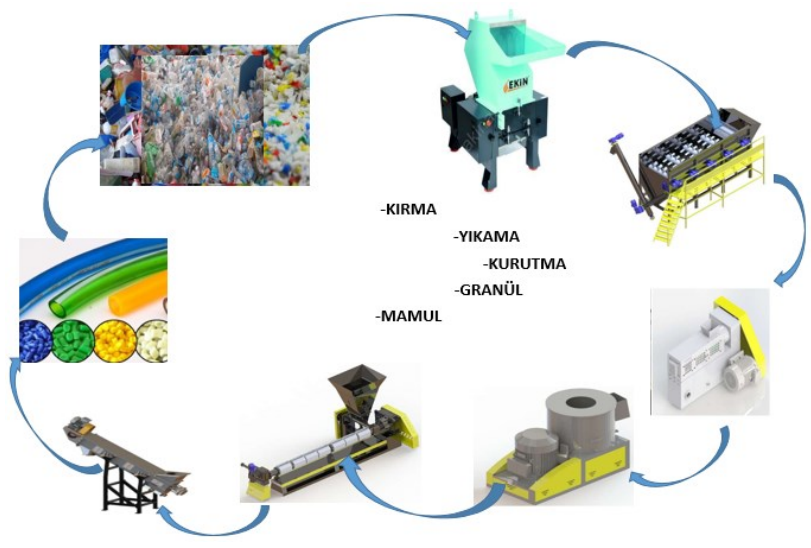

Atık plastiğin geri dönüştürülmesinde Şekil 1'de döngü şeması verilen makine süreci incelendiğinde aşağıdaki şekilde döngü tamamlanır. Toplanan atık plastiğin cinsine göre ayrıştırma yapılır. Kullanım ömrünü tamamlamış polimerlerin bir kolu olan; Termoplastik içindeki PP, PVS, PC, PS, HDPE, LDPE vb. atıklar ayrıştırılarak depolanır. Ayrıştırılan atık termoplastikler kirlilik açısından kirli olan ve olmayan, renk açısından beyaz mavi sarı vb. olan ve cinsine göre ayrıştırma yapılır. Yukarı da bahsettiğimiz ayırma Şekil 2'de görüldüğü üzere tamamlanmış olur.

Şekil 2: Termoplastik (PP, PVS, PC, PS, HDPE, LDPE) ayrıştırma[8]

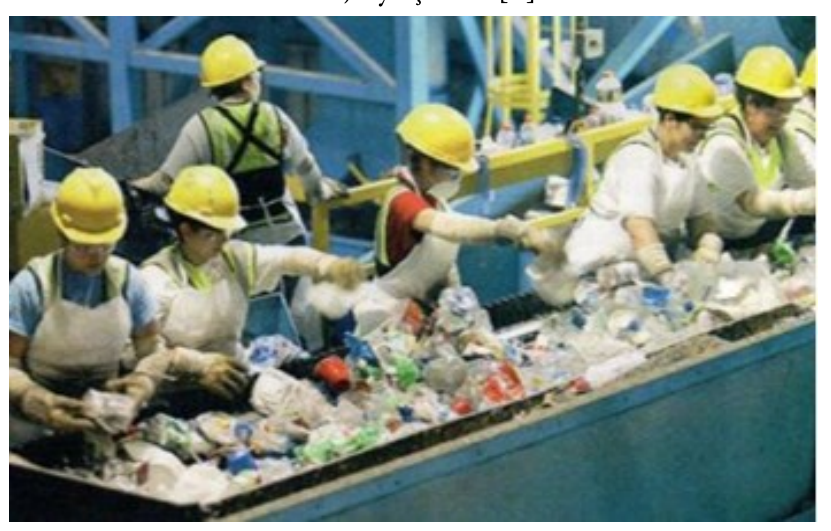

Ayrıştırılması bitmiş termoplastikler Şekil 3(a-b-c)'de görülen dışarıdan yataklı balta, yıldız ve blok tipi plastik kırma makinesinde kırılarak şekil 3d'de verilen çapak (2) 
haline getirilir.

Şekil 3: Plastik kırma makinelerinin rotor yapıları ve pet çapağ ${ }_{1}[8]$

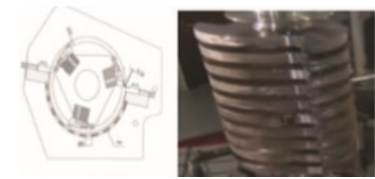

a) Balta kırıcı b)Yıldız kırıcı

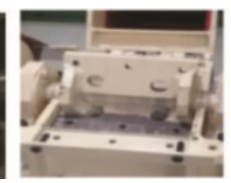

c) Blok Kırıcı

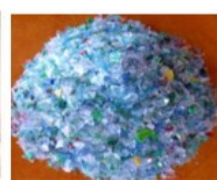

d) Pet çapağı
Plastik kırma makinesinde kırılmış plastik çapak taşıyıcı helezon vasıtası ile yıkama havuzuna aktarılır. Yıkama havuzu geri dönüşüm sürecini üçüncü safhasıdır. Atık plastikler toplandıklarında genelde topraklı ve kontamine olmuş durumdadırlar.Plastik yıkama havuzları (Şekil 4) yapılan işin büyüklüğüne göre ön, orta ve yüksek şeklinde yıkama kademelerinden oluşmaktadır. Ön kademede kırılmış plastik çapağın kaba kiri alınır. Orta kademede $\% 40$ ile \% 80 arası plastik çapak kirlilik den arındırılır. Plastik çapak, yüksek kademede temizleyi maddelerle (klor, köpük giderici, vb.) plastik çapak yıkanarak işlem tamamlanır.

Şekil 4: Balkonlu ve balkonsuz yıkama havuzu[8]

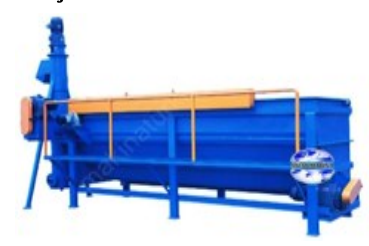

a) Balkonsuz Yıkama Havuzu

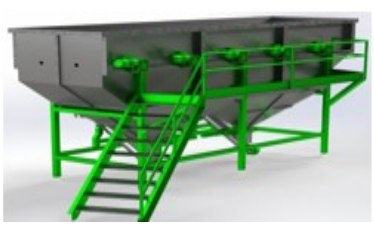

b) Balkonlu Yıkama Havuzu
Silindirik yatay sıkma makinesinin çalışması ve çapağın susuzlaştırmasını incelendiğinde; kovan çevresinde uygun ölçüde delikler mevcuttur. Kovan içindeki helezona aktarma organından (redüktör) uygulanan tork sslak plastik çapağın kovan ile helezon arasında kalarak sıkışır. Kovan içindeki dairesel hareket halindeki helezon plastik çapağ ileri doğru gönderir. Plastik çapak kovan çıkışında ağızında bulunan kapı görevi yapan konik sayesinde plastik çapağa tepki kuvveti uygulayarak plastik çapağın susuzlaşıırmasına ortam yaratır. Şekil 5'de kovan, helezon ve konik görülmektedir. Etki (kovan içindeki helezonun ilettiği plastik çapak) ve tepki (kapı görevi yapan konik) kuvvetleri kovan ile konik mesafenin ayarlaması ile değiştirilebilir. Bu kovan (plastik çapağın sıkıştırıldığı hacim) ile konik(kapı görevi görmektedir) mesafe ayarı makinenin saate susuzlaştıracağ ürün kalitesini ve üretim kapasitesini belirlemektedir.

Şekil 5: Yatay plastik sıkma makinesinin kısımları[8]

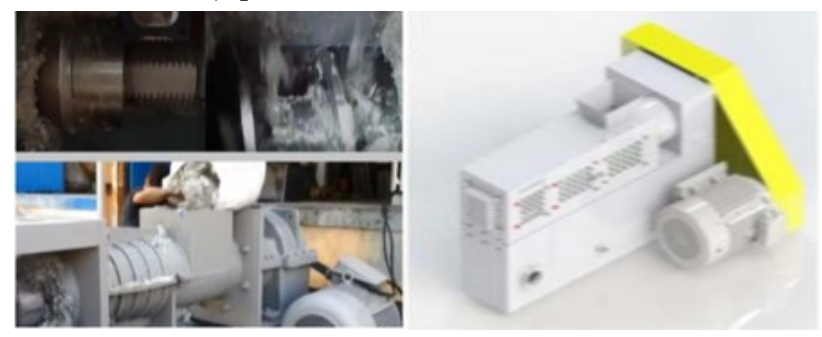

Sıkma işlemi tamamlanan plastik çapak taşıyıcı helezonlar vasıtasıyla agromel makinesine aktarilır. Agromel makinesinde ürün elde etme; kazanın içine düşen çapak yüksek devirde dönen bıçaklar ile kazana sabitlenmiş bıçaklar arasında kalarak küçülür. Kesilirken ısınan plastiğe şoklama yapılır. Bu durum şoklama plastiğin kurumasına ve tok taneler haline gelmesine sebep olmaktadır. Şekil 6'da silindirik akromeller görülmektedir.

Şekil 6: Yatay plastik sıkma makinesinin kısımları[8]
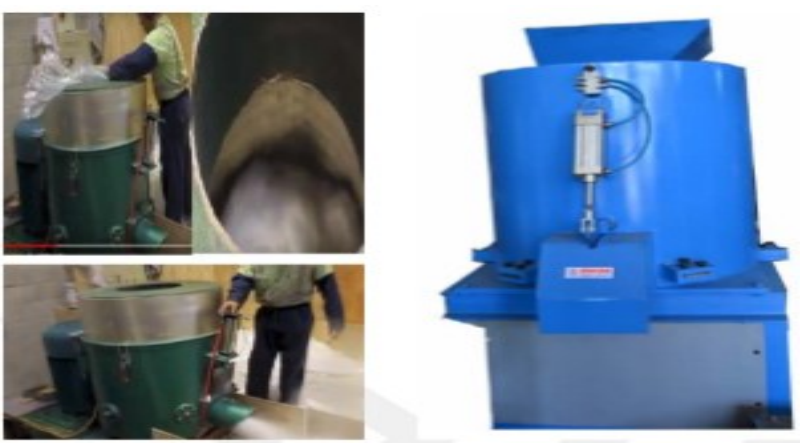

Granür makinesine gelen çapak plastik temizlenmiş ve kurutulmuş şekilde gelir. Plastik eriyik haline geldiği kısım kovan bölümüdür. Kovanın ısıtılmasında elektrik direncinden yararlanılır. Seramik rezistanslara içinde yerleştirilmiş elektrik dirençi yüksek malzemeden yapılmış teller mevcuttur. Rezistansların içindeki teller elektrik akımı verilir direnç oluşturur tel ısınır, ısınan telden rezistansa iletim yolu 
ile 151 transferi olur. Daha sonra seramikten kovana ve plastik çapağa iletim yolu ile ısı transferi olur ve ısınan plastik eriyik hale gelir.

Kovan içindeki vida dairesel hareket etmektedir. Plastik çapağın granül haline gelmesi, kovan içindeki vidanın yanaklarının itme kuvveti meydana getirmesiyle gerçekleşmektedir. Eriyik plastik iki farklı şekilde kesme işlemi yapılarak granül haline getirilmektedir. Tesbih tanesi büyüklüğün de granül elde etme ise bu sistemin son halkasıdır. Şekil 7’de ekstüruzer ve mekanizmaları görülmektedir.

Şekil 7: Ekstüruzer ve mekanizmaları[8]

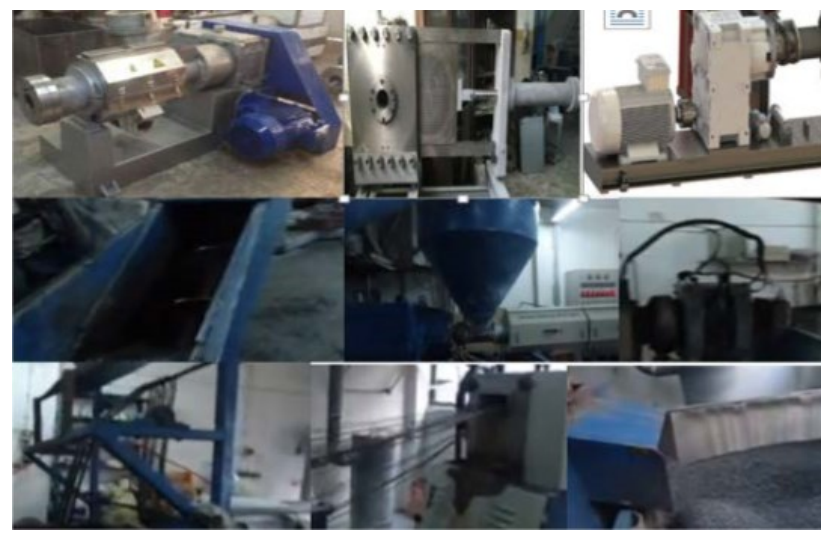

Santrifüj fanı(a) kesilen granülü ve kesim sırasında oluşan plastik tozunu da emer ve depolama silosuna(b) entegre olan filtre ve siklon (havadaki plastik partiküllerin toplandığı bölüm) ünitesine gönderir.Siloda depolanan plastik açılıp kapanabilen vana vasıtası ile çuvallara depolanır. Siklon ünitesi ve filtre mekanizmaları çalışma ortanım da toz oluşumunu önleyen mekanizmalardır. Şekil 8(a-b)'de fan ve toplama filosu görülmektedir.

Şekil 8: Toplama filosu ve taşıyıcı fan[8]

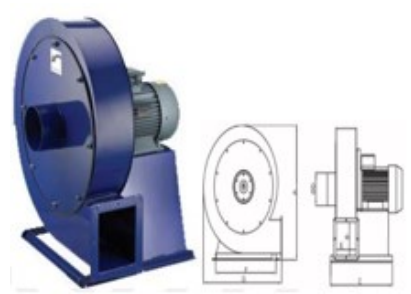

a) Fan

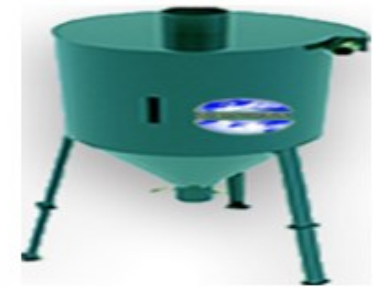

b) Toplama silosu
Son aşamada atık plastik granül halde iken (8) nolu aşamada mamul üretimi için depolama alanına bekletilir. Şekil 9' da sırasıyla enjeksiyon(a), şişirme(b) ve bunlara benzer makinelerde tekrar Şekil 10'da görseleri verilen (17) numaralı mamul üretimiyapılmak üzere depodan makine ve istasyonlara dağıtımı yapılır.

Şekil 9: Enjeksiyon(a) ve şişirme makinesi(b) [8]

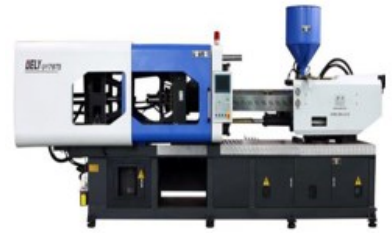

a) Enjeksiyon Makinesi

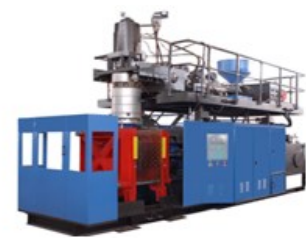

b) Şişirme Makinesi
Enjeksiyon ve şişirmede üretimi yapılan mamullarincelendiğinde; Pet Şişe(1): Polietilen tereftalat (PET veya PETE veya PE). Su, yağ ve meyve suyu şişeleri tek kullanımlık mamuller olup içi dolu iken 1sıya maruz bırakıldığında mamulün zehirli, kimyasalları sıvıya bulaşır. HDPE(2) Polietilen, LDPE(4) Polietilen, PP(5) Polipropilenen çok kullanılan plastik olup kırılmaya dayanıklıdır. Süt, su, çamaşır suları, motor yağları kapları vb. kullanılır ve gerekli hijyen koşulları sağlandığında birden fazla kez kullanım için uygundurlar. PVS(3) Polivinil, PC(7) işaretli pet şişeler yiyecek ve içecek için uygun değildirler. PS(6) Polistren çok yönlü kullanılan plastiktir. Özellikle yiyeceklerin koruyucu paketlemesinde kullanılmaktadır.

Şekil 10: Enjeksiyon ve şişirmede üretimi yapilan mamullar[8]

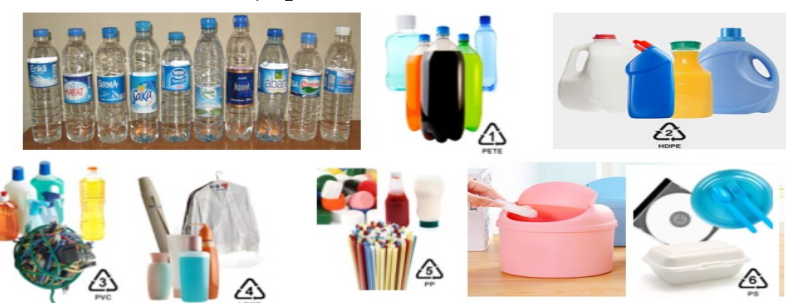


Tablo 8: Tehlike derece numarası sistemi[9]

\begin{tabular}{llll}
\hline OMGO & TBBS & OYŞ & RAKKS \\
\hline $0,003<$ Neredeyse imkansız & $0,5<$ Yılda 1 & $0,1<$ Çizilme sıyrılma & $1<1-2$ Kişi \\
$1<$ Çok zor & $1<$ Ayda 1 & $0,5<$ Kesilme yırtılma & $2<3-7$ Kişi \\
$2<$ Olası & $1,5<$ Haftada 1 & $1<$ Küçük kemik kırılması (parmak) & $4<8-15$ Kişi \\
$5<$ Muhtemelen & $2,5<$ Günde 1 & $2<$ Büyük kemik kırılması (el. Kol,bacak) & $8<16-50$ Kişi \\
$8<$ Mümkün & $4<$ Saate 1 & $4<1$ veya 2 parmak kaybı & $12<X>50$ Kişi \\
$10<$ Yüksek ihtimal & $5<$ Sürekli & $8<$ El kol, bacak kaybı kısmen işitme ve görme kaybı \\
$15<$ Kesin & & $10<2$ El kol, bacak kaybı tamamen işitme ve görme kaybı \\
& & $12<$ Ciddi kalıcı hastalık \\
& & $15<$ Ölümcül \\
\hline
\end{tabular}

\section{MATERYAL VE YÖNTEM}

Çalışmada MORD kullanılarak; HRNS metoduyla termoplastik geri kazanım sürecinde kullanılan makinelerdeki tehlikelerden yalnızca birer tanesine proaktif yaklaşımla risk değerlendirmesi uygulanmıştır. $H R N S$ 'nin skalaları$\mathrm{n} ı$ incelediğimizde; OMGO: olayın meydana gelme olasılığ 1 (0,003-15), TBBS tehlikeli bölgede bulunma sıklığ 1 (15), OYŞ olası yaralanmanın şiddeti (0,1-15), RAKKS risk altında kalan kişi sayısı (1-12) gibi sayısal derecelendirmeler kullanılarak risk skoru aşağıdaki formül kullanılarak bulunmuştur. HRNS nin uygulanmasında kullanılan tehlike derece numarası sistemi Tablo 8'de değerlendirme aralıkları ile verilmiştir.

\section{HRNS $=($ OMGO X TBBS $)$ X(RAKKS X OYŞ $)$}

\section{HRNS= OLASILIK X ŞİDDET}

Sonuç değerlendirme İER ihmal edilebilir risk (0-1), ÇDR çok düşük risk (2-5), DR düşük risk (6-15), DDR dikkate değer risk (15-50), ÇYR çok yüksek risk (51-500), AYR aşırı yüksek risk (501-) şeklinde görülmektedir. Ayrı- ca Tablo 8 ve 9'da tehlikenin değerlendirmesinde kullanılan skalalar verilmiştir. Tablo 9'de görüldüğü üzere skala sonuçları (0-13500) arasında olabilmektedir.

\section{BULGULAR}

\section{A. Proseste 5 Makinenin Çalışma Şekli ve 5 Tehlikenin} MORD ile Değerlendirme Uygulaması

\section{Tehlike Nedeni ve Çözüm(O1)}

Plastik kırma makinesinde en önemli tehlike elle malzeme beslemesi yaparken elin $600 \mathrm{~d} / \mathrm{d}$ ile dönen rotora(1) kaptırılma sonucu oluşan (el veya ayağın, kırılacak malzemeye sarılması ile rotorun(1) üzerine davlumbaz(7) ağzından (12) çekmesi) tehlikedir. Örnek olarak motor(10) gücü 12,5 kw hesaplanan bir kırma makinesinin bir bıçağında oluşan kesme kuvveti 2250Newton (N) olarak hesaplanmıştır. Bu hesaplama kırılacak malzeme cinsi, rotor(1) çapı farklı olduğunda değişmektedir.

Çalışanın 2250N'luk kesme kuvvetine karşı koyması mümkün olmayacağı örnek olayda görülmektedir. Kesme işlemini yapan şekil 11b'de görülen (18) numaralı kesici

Tablo 9: Tehlike derece numarası sistemi[9]

\begin{tabular}{|c|c|c|}
\hline HRNS & RiSK & AÇIKLAMA \\
\hline $0-1$ & İhmal Edilebilir Risk & Mevcut durumda sağlık ve güvenliği tehlikeye atacak risk yok, ilave emniyet tedbirlerine ihtiyaç yok. \\
\hline $2-5$ & Çok Düşük Risk & $\begin{array}{l}\text { Mevcut durumda sağlık ve güvenliği atan çok az risk var, ilave olarak kayda değer bir emniyet tedbirlerine } \\
\text { gerek olmayabilir. Personel koruma ekipmanları kullanılabilir ve eğitimlerle risk azaltılabilir. }\end{array}$ \\
\hline $6-15$ & Düşük Risk & Az da olsa risk vardır. Emniyet tedbirleri için gerekli kontrol ekipmanlarının kullanılması önerilmektedir. \\
\hline $16-50$ & Dikkate Değer Risk & Emniyet tedbirlerinin alınmasını gerektirecek seviyede risk vardır. İlk firsatta bu tedbirler uygulanmalıdır. \\
\hline $51-100$ & Yüksek Risk & $\begin{array}{l}\text { Acil olarak emniyet tedbirleri alınması gerekecek kadar potansiyel tehlike vardır. Bu tedbirler acil olarak } \\
\text { uygulanmalıdır. }\end{array}$ \\
\hline $101-500$ & Çok Yüksek Risk & Acil olarak emniyet tedbirleri alınmalı. İlgili yönetim birimleri haberdar edilmelidir. \\
\hline 501- & Aşırı Yüksek Risk & $\begin{array}{l}\text { Acil olarak emniyet tedbirleri alınmalı, yeterli kontrol tedbirleri alınıncaya kadar ekipmanlar kullanılmalı, } \\
\text { insanlar uzak tutulmalı ve ilgili birimler haberdar edilmelidir. }\end{array}$ \\
\hline
\end{tabular}


ağızdır.

Şekil 11: Blok tipi plastik kırma makinesi[8]
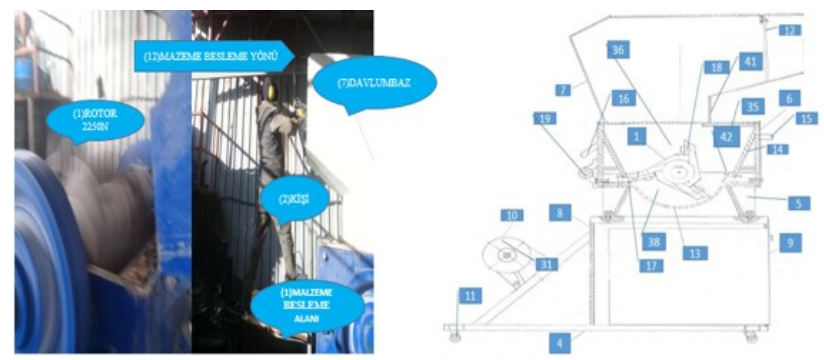

a) Kırma Makinesinde Elle Besleme b) Blok Tipi Kırma Makinesi

Elle çalşsma tehlikesi şekil 11(a-b)'de görüldüğü üzere çalışanın kırma ağzında (12) malzemeyi beslemesi ile başlayan ve kırılacak malzemeyi rotora (1) doğru ittirmesi sırasında elin kırılan malzemeye sarılması sonucunda 600-800 $\mathrm{d} / \mathrm{d}$ ile dönen rotorun(1) çalışanı gövde (36) içine çekilmesidir. Risk değerlendirilmesi 1125 ve 0,5 olarak değerlendirilmiştir.

Tehlikenin ortadan kaldırılmasında Şekil 12b’ de görülen taşıyıcı bant kullanılması çalışanların tehlike bölgede bulunma süresini (TBBS) ortadan kaldırarak 2,5 düşürmüştür. Taşıyıcı bant kullanımı olayın meydana gelme olasılığını (OMGO) çok zor olasılık haline getirerek 1 sayı değerine inmiştir. Risk alanından uzaklaşılmış ama çalışan kişi sayısı (RAKKS) 1 sayı değeri değişmemiştir. Çalışanın tehlikeden uzaklaştırılması ile riskin bertaraf edilerek olası yaralanma şiddeti (OYŞ) 0,5 sayı değerine minimize edilmiştir.

Şekil 12: Elle besleme ve taşıyıcı bantla çalışma

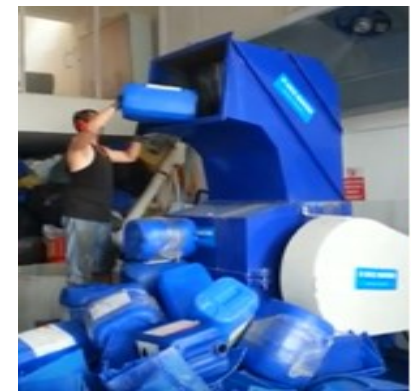

a) Elle Besleme Tehlikesi a)-HRNS=15X5X1X15=1125

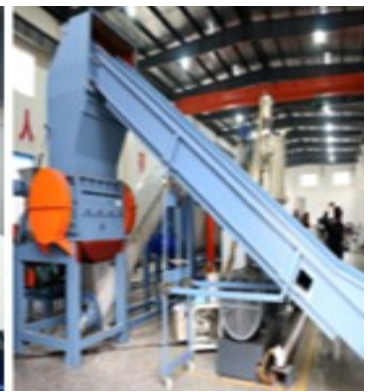

b) Cözüm Karşı Taşıyıcı Bant b)-HRNS=1X2,5X1X0,1=0,25

\section{Atık Termoplastik Yıkama Havuzu (O2)}

Atık Plastik Kırma makinesinde kırılan plastik hurda çapak halinde gelir. Kırılmış plastik çapak hacimce küçülmüş olarak helezon vasıtası ile havuza aktarılır. Havuzun seperatörleri dairesel hareketi ile çapağı yüzdürür ve yıkanmasını sağlar. Havuz içinde temizleyici olarak kullanılan su ve temizlik maddeleri(klor, vb.) ile çapak kirinden arındırılır ve temizlenen çapak havuz üzerinde bağlı taşıyııı helezonla havuz dışına alınır. Havuzların ölçüleri yıkanacak malzemenin cinsine ve temizlik bağlı olmakla beraber genelde boyu 4-5-6 m, genişlik 1,4-2,3m ve yükseklik 1,52,5 m şeklindedir. Şekil 13(a-b)' de yıkama havuzları görülmektedir.

Atık Plastik Yıkama havuzunun en tehlike yaratan kıs$\mathrm{m} ı$ havuz içindeki plastik çapağın taşıma ve hareketlendirme yaparak temizlenmesini sağlayan ve dairesel (40-60 d/ d) hareket eden seperatördür. Çalışan personelin havuz içinde yıkanan plastik çapağı elle karıştırma yapılması sonucunda personelin havuzun içine çekilmesi tehlikesidir. Şekil 13b’ de görüldüğü üzere birincisi önlem yıkama havuzunda koruma tablaların çalışanın havuzun içine müdahale edemeyeceği şekilde yükseltilmesidir.

Şekil 13: Kırılmış atık plastiklerin yıkanmasında kullanilan havuzlar[10]

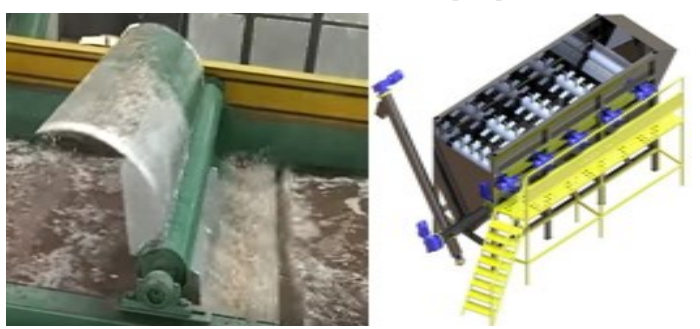

a) Uygun Olmayan Yıkama Havuzu b) Uygun Yıkama havuzu

İkincisi aktarma organında kullanılan zincir yerine (V) kayışı tercih edilmelidir. Üçüncüsü ise redüktörden seperatöre direk aktarma hareketi oluşturan minimum (kw) güçte redüktör kullanılmalıdır. 


\section{Silindir Tipi Plastik Sıkma Makinesi (O3)}

Makine üzerinde sabit olan elektrik motorundan kayış kasnak vasıtasıyla redüktöre hareket verilir. Oluşturulan tork hareketi, rediktörden kovan içindeki helezona iletilen itme (dönme momenti) kuvvetidir. Kurutma işlemi şu şekilde gerçekleşir. Tork oluşumu Şekil 14b'de oluşması gösterilmiştir. Kovan içindeki helezona aktarma organından uygulanan tork sslak plastik çapağın kovan ile helezon arasında kalarak sıkışır. Kovan içinde sıkışmış plastik çapağın suyu kovan çevresindeki deliklerden dışarı sızar. Kovan içindeki dairesel hareket halindeki helezon plastik çapağı ileri doğru gönderir. Plastik çapak, kovan çıkışında bulunan kapı görevi yapan ayarlanabilir burç plastik çapağa tepki kuvveti uygulayarak susuzlaştırmayı sağlar. Şekil 14a’ da kovan, helezon ve konik görülmektedir. Etki (kovan içindeki helezonun ilettiği plastik çapak) ve tepki (kapı görevi yapan konik burç) kuvvetleri kovan ile konik mesafenin ayarlaması ile değiştirilebilir. Kovan (plastik çapağın sıkışıırıldığı hacim) ile konik burç(a)(kapı mesafe ayarı yapar) mesafe ayarı makinenin saatte susuzlaştıracağı ürün kalitesini ve üretim kapasitesini belirlemektedir.

Şekil 14: Silindirik sıkma makinesinde tork oluşumu gösterimi[10]

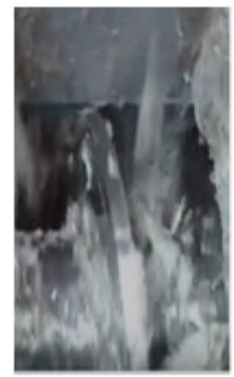

a) Silindir S $1 \mathrm{kma}$

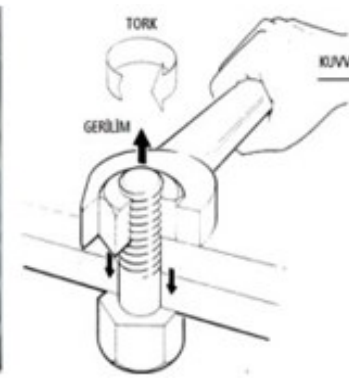

b) TorkOluşumu

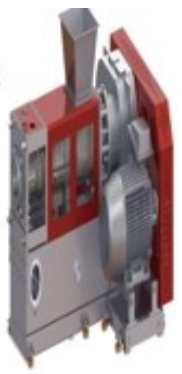

c) Korumalı Sıkma
Şekil 14'de görülen Plastik sıkma makinelerinde motor ve şanzıman arasında kayış kasnak vasıtasıyla aktarım yapan organlarının korumasız çalışırıılmaları uzuv kayıpların neden olabilmektedir. Kandırmalı (manipülasyon yaratmayan) olmayan, yerinden sökülmeyen söküldüğünde siviçile ana motorun çalışmasını engelleyen tasarımlı makineler kullanılmadır.

\section{Ekstruder (Granül) Makinesinin (O4)}

Ekstruder (granül) makinesine gelen çapak plastik temizlenmiş ve kurutulmuş şekilde gelir. Plastik eriyik haline geldiği kısım kovan bölümüdür. Kovanın ısıtılmasında seramik rezistanslar kullanılır. Kovan içinde ısınan plastik eriyik hale gelir. Makinenin motor ve şanzımanından aktarılan güçlü tork ile kovan içindeki eriyik kovan içindeki vida marifeti ile süzgeç mekanizmasına taşınır. Şekil 15a' da plastik eksturuder (granül) makinesi görülmektedir.

Şekil 15: Plastik eksturuder makinesi ve havlandırma Görselleri[6]

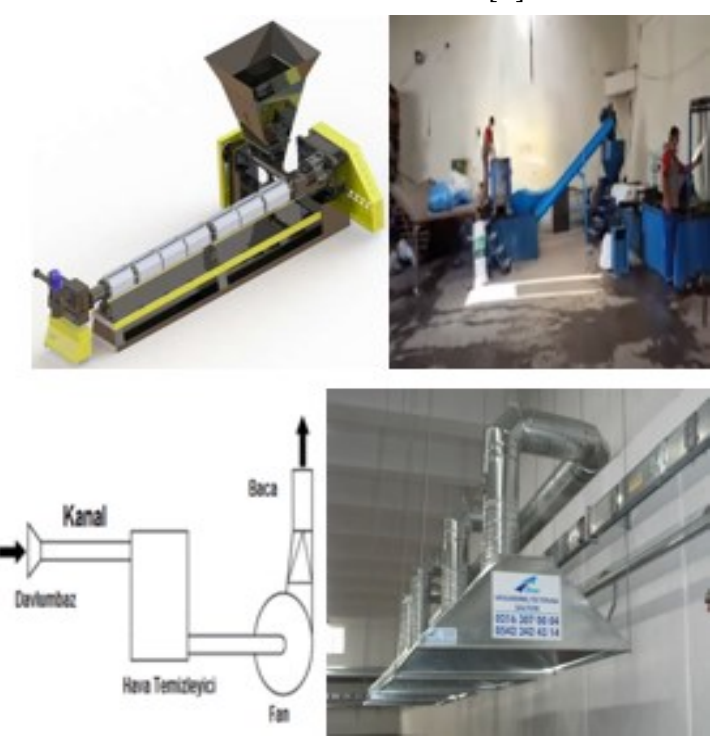

a)Ekstruder b) Kanalsız ortam c) Şeması d) Kanallı ortam

Ekstruder makinesinin kullanım alanlarında işlenen atık plastik çapağına bağlı olarak gaz, buhar, sis ve duman ortama yayılmaktadır. Bu maddeler çalışma ortamını kirletip, çalışan sağlığını olumsuz yönde etkilemektedir. Personeli çalışma ortamına yayılan gazlardan etkilenmemesi için önce ortamın lokal egzoz havalandırma mekanizması kurulmalıdır. Lokal egzoz havalandırma mekanizmasının çalışma sisteminin kısımları; davlumbaz veya açıklık, kanallar, hava temizleme cihazı, fanlar ve egzoz bacası Şekil 
Tablo 10: Ön tehlike analizi - PHA

\begin{tabular}{|c|c|c|c|c|}
\hline Olay & Sebepleri & Etkileri & $\begin{array}{l}\text { Şiddeti / } \\
\text { ihtimali }\end{array}$ & Önlem \\
\hline O1-Dönen Rotora (1) Çekilme & Elle Besleme & Uzuv Kaybı ve ölüm & $1 / \mathrm{A}$ & $\begin{array}{l}\text { Şekil4b 'deki Taşıyıcı Bant Kula- } \\
\text { nımı }\end{array}$ \\
\hline $\begin{array}{l}\text { O2-Yıkama Havuzuna Düşme veya } \\
\text { Çekilme }\end{array}$ & Elle yıkanan çapağa müdahale & Yaralanma uzuv kaybı & $2 / A$ & $\begin{array}{l}\text { Şekil5b 'deki Uygun Yıkama } \\
\text { Havuzu }\end{array}$ \\
\hline O3- Dönen Aksama Sarılma & Dikkatsiz çalışma & Yaralanma uzuv kaybı & $1 / B$ & $\begin{array}{l}\text { Şekil6c 'deki Aldatmasız Koruma } \\
\text { Kullanma }\end{array}$ \\
\hline O4-Ortamdaki Gaz & Mekanik Havalandırma yok & Meslek Hastalığı & $1 / \mathrm{A}$ & $\begin{array}{l}\text { Şekil7d 'deki Hava Kanallı Cebri } \\
\text { Havalandırma }\end{array}$ \\
\hline O5- Silindir Bıçağa El Kaptırma & Korumasız kesici ağız & Yaralanma uzuv kaybı & $2 / B$ & $\begin{array}{l}\text { Şekil9c 'deki Tasarımı Uygun } \\
\text { Kullanım }\end{array}$ \\
\hline
\end{tabular}

15c'de görülmektedir. Sistemin çalışmasına bakıldığında, kirli hava çalışma alanından emilerek kanala yol verilir. $\mathrm{Bu}$ yol vermede hava ile ortamdaki gazın yoğunluk farkından yararlanılır. Havadan hafif olan gazın yukarı çıktığında toparlanma kanalına (davlumbazda) ulaşır. Hava temizleme cihazından geçen kirli hava, taşıma kanallarında ilerleyen hava fanlar vasitasiyla emilerek ortamdan egzoz bacaları vasıtasıyla uzaklaştırılır. Şekil 15b'de Havalandırma tertibatı olmayan işyeri ortamı, Şekil 15 d'de ise havalandırma cihazları olan işyeri ortamı görülmektedir.

\section{Düz Granül Kesme Makinesi (O5)}

Eriyik plastik iki farklı şekilde kesme işlemi yapılarak granül haline getirilmektedir. Birincisi eski teknoloji olan ve halen kullanılan ekstruderin çıkış ağzında bulunan süzgeç mekanizmanın eriyiği süzmesi ve belirli çapta ip şeklinde akıtılır. Akıtılan eriyik soğuk su dolu yavuz içinden geçerken katılaşır ve düz silindirik kesme makinesinde tespih hacminde kesilir. Şekil 16'de silindirik tespih şeklinde kesme makinesinin kısımları görülmektedir.

Şekil 16: Silindirik tespih şeklinde kesme makinesinin kısımları[10]
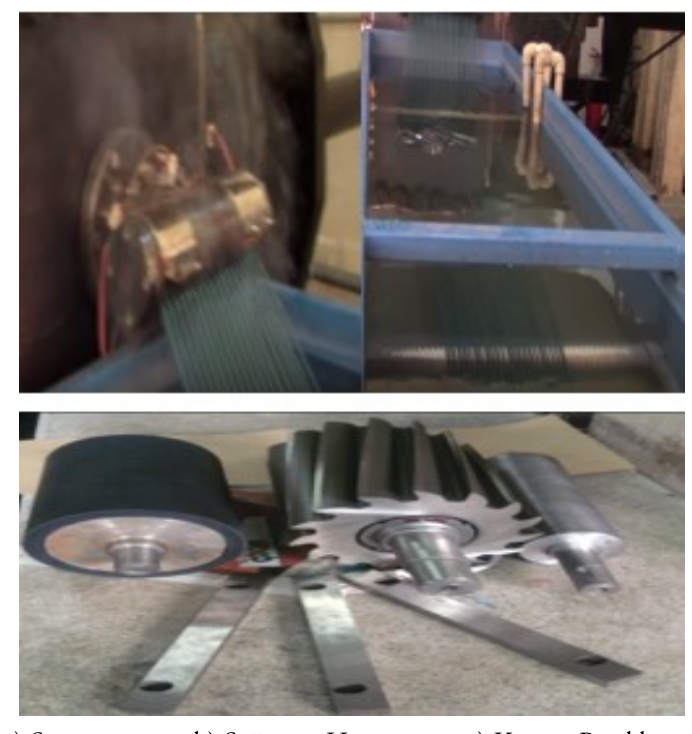
a) Süzgeç
b) Soğutma Havuzu
c) Kesme Bıçakları

İkincisi kesme işlemi; eriyik plastik kafadan kesme mekanizması kullanılarak tespih hacminde çok taneli olarak kesilerek taşıma ve soğutma işlevi gören suya düşerek sant-

Tablo 11: Tehlike derecelendirme numarası sistemi - HRNS

\begin{tabular}{cccccc}
\hline HRNS & RAKKS & TBBS & OMGO & OYŞ & $\begin{array}{c}\text { ILK } \\
\text { TDNS }\end{array}$ \\
\hline O1 & 1 & 5 & 15 & 15 & 1225 \\
$\mathbf{0 2}$ & 1 & 5 & 15 & 12 & 900 \\
$\mathbf{0 3}$ & 2 & 5 & 10 & 12 & 600 \\
$\mathbf{O 4}$ & 2 & 5 & 10 & 12 & 600 \\
$\mathbf{0 5}$ & 1 & 5 & 10 & 8 & 400 \\
\hline HRNS & RAKKS & TBBS & OMGO & OYŞ & ILK \\
\hline O1 & 1 & 0,5 & 0,5 & 0,5 & 0,25 \\
O2 & 1 & 5 & 0,5 & 0,5 & 2,5 \\
O3 & 2 & 5 & 0,5 & 0,5 & 5 \\
O4 & 2 & 5 & 0,5 & 0,5 & 5 \\
O5 & 1 & 5 & 0,5 & 0,5 & 2,5 \\
\hline
\end{tabular}


Tablo 12: HRSN ve PHA karşılaştırma analizi

\begin{tabular}{ccccc}
\hline $\begin{array}{c}\text { Risk Yöntemi } \\
\text { Eylem }\end{array}$ & Yüksek & Ciddi & Aşırı Yüksek & Çok Yüksek \\
\hline O1 & 1 & & 1 & \\
O2 & 1 & 1 & \\
O3 & 1 & 1 & \\
O4 & 1 & 1 & 1 \\
O5 & 1 & & & 20 \\
\hline$\%$ & 100 & 0 & 80 & \\
\hline
\end{tabular}

rifüje geçer. Şekil 17a' da kafadan kesme mekanizması kısımları görülmektedir. Santrifüjde susuzlaştırma yüksek devirde dönen delikli şaft ile yapılmaktadır. Dikeyde dairesel hareketle çalışan delikli şaft içindeki granül yukarı taşınırken su aşağıya düşerken (yer çekim kuvvetinden dolayı) granül yukarı taşınmış olur. Yukarıya taşınan granül suyundan \% 95 kadar ayrıştırır. Şekil 17b' de görülen dikdörtgen biçimli santrifüj ve kısımları görülmektedir[6]. Şekil 16b’ de görülen soğutma havuzundan çıkan katılaşmış iplik şeklindeki çoklu granülün, dönerek kesme işlemi yapan Şekil 17c'de görülen haznesine elle verilerek kesme işlemi başlatılır. Kesme hanesine verilen $4 \mathrm{~mm}$ çapında iplik şeklindeki granül kesme hanesine doğru sürülmemesi ayr1ca makine kesim ağzının koruma olmamasından dolayı elin ve parmakların kaptırılması sonucunda uzuv kayıpları yaşanmaktadır. Bu kazalar tesbih biçimli düz kesim yapan makinenin ilk kesim ayarı yapılması sırasında olan tehlikeli durumdur. Düz kesmelerde granül kesicilerinin ön kısmı korumasız çalıştırılmamalıdır. Şekil 17'de korumalı düz kesim makinesi görülmektedir.

Şekil 17: Silindirik tespih şeklinde kesme makinesinin kısımları[10]

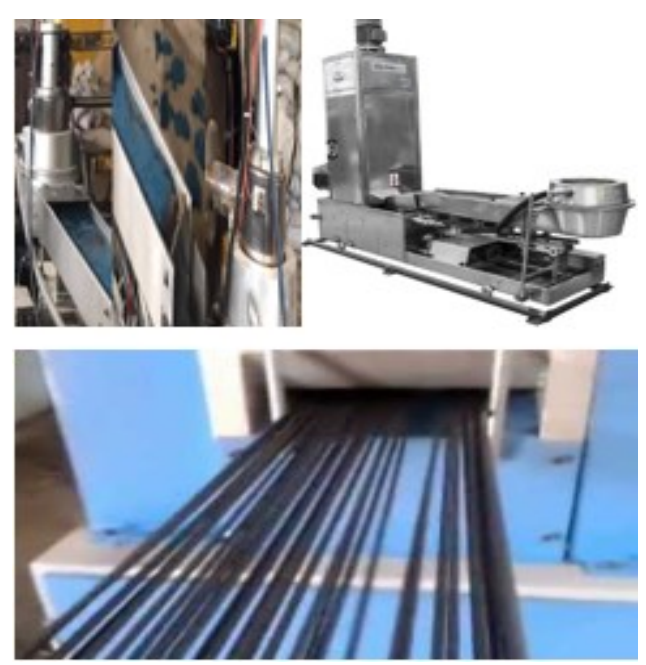

a) Kafadan Kesme b) Santrifüj Makinesi c) Düz Kesme

Soğutmanın su ile yapılması nedeniyle granüller, santrifüjde susuzlaştırma yapılarak fan marifeti ile Şekil 18'de görülen depolama silosuna gönderilir. Depolama alanından enjeksiyon, şişirme ve bunlara benzer makinelerde tekrar mamul üretimi yapılmak üzere cinsine göre dağılımı yapılir.

Şekil 18: Depolama silosu ve hammadde (granül)[10]

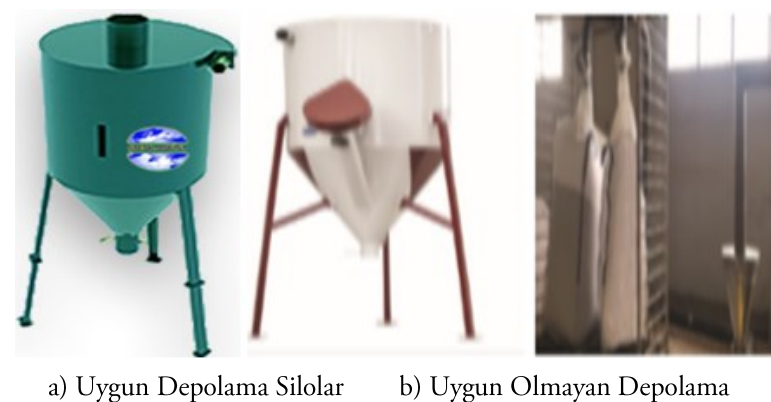

\section{B. Proseste 5 tehlikenin MORD Değerlendirme Sonuçları}

Atık plastiklerin sanayiye tekrar kazandırmasında kullanılan makineler; hidrolik presler, giyotin makas, seperatör elek, şerit testere, taşıyıcı bant, plastik kırma makinesi, taşıyıcı helezon, yıkama havuzu, sıkma makinesi, agromel makinesi, extruder makinesi, kafadan kesme ekipmanı, iletici fanı ve depolama haznesi gibi makineler kullanılmaktadır. Bu süreçte en tehlikeli makine olarak yaptığı işlev itibari ile plastik kırma makinesi gelmektedir. Günümüzde 
bu sürecin çevreye katkısı yanında kullanıılarının karşılaştıkları beş farklı makinede var olan veya olabilecek tehlikeli olay incelenmesi yapılarak taraflara çözüm öneriler sunulmuştur. İki farklı risk değerlendirme metodu ile termoplastik geri dönüşüm sürecinde kullanılan; plastik kırma, yıkama havuzu, silindir sıkma, ekstruder ve düz kesme makinelerinde birer tehlikenin risk değerlendirmesi yapılmıştır. PHA[11] kalitatif bir uygulamadır. Risk ifade edilirken; sayısal değerler yerine, tanımlayıcı olan çok yüksek, yüksek ve düşük gibi değerler kullanılır. Tablo 10'de PHA ile var olan tehlikelerin tespitinde ve diğer metotlara veri oluşturmada kullanılmaktadır.

HRNS ile plastik geri dönüşüm makinesinde proaktif yaklaşımla tespit edilen tehlikeli beş olayın risk değerlendirmesi yapılmıştır. O1, O2, O3, O4, O5'deki tehlikeli olayların risk değerlendirmesinde çıkan sonuçlara göre hem sözel hem görsel şekiller kullanılarak çözüm önerileri getirilmiştir.

Yapılan bu çalışmada risk değerlendirmesi ilk kullanılan metot değerlendirmesi Tablo 10'da yapılmış PHA metodudur. Veriler incelendiğinde sonuçların \% 100'nün yüksek ve \% 0'nın da ciddi olduğu, Tablo 11'deki HRNS metodunu incelediğimde ise sonuçların \% 80'nin aşırı yüksek ve $\% 20$ 'nin yüksek olduğu görülmüştür. Tablo 12'de HRNS ve PHA karşılaştırma analizinde, çıkan sonuçların bize tehlikenin bertaraf edilmesinde uygulanan risk değerlendirme metodunun doğru seçilmesinin önemli olduğu ortaya çıkmıştır. Diğer taraftan tehlike algılamasında risk değerlendirmesini yapan İSG uzmanının da tecrübesi (ilgili alanda çalışı̆̆ı yıl) ve uzmanlık (eğitim aldığı alan) alanı yapılan değerlendirmenin sonunun etkilemektedir.

$\mathrm{Bu}$ çalışmada işlediğimiz beş tehlikenin en önemlisi kırma makinelerinde elle besleme tehlikesidir. Bu tehlike- nin olasılık skalasının düşük olması, tehlikenin önemsenmemesine neden olmaktadır. Burada önemli nokta aslında şu olmalıdır. Kaza meydana geldiği andan itibaren şiddetinin ortaya koyduğu durum bize bir olayda ortaya çıkacak sonuç, katlanılmaz acılara neden olacak ise olasılık skalasının en yüksekten algılanmasının akılcı bir yaklaşım olacağını söylemektedir.

\section{C. Örnek Siviç Uygulamasının TS EN 12100, TS EN}

\section{9 ve TS EN 61508 Standart Bakışı ile MORD}

İşletmelerde risk değerlendirmesinin ilk sırasında proaktif yaklaşıma uygun olan PHA gelmektedir. Risk sonuçunu etkileyen tehlikeli olayları, bu tehlikeli olayları önemi, tehlikenin hangi metodla daha akılcı olacağı ortaya konabileceğininoktasında bir kılavuz durumundadır.

Ön tehlike analizinin belirlenesinin sıralaması;

- Potansiyel tehlikeli elemanlar,

- Tehlikeli durumlar,

- Tehlikeli olaylar,

- Emniyet sistem kayıpları,

- Geçmiş kaza olayları veri olarak kullanılır.

Yoğun makine ve mekanizmalarının bulunduğu termoplastik geri kazanma işletmelerinde MORD ile yapılmak durumundadır. Makine ve makine süreçlerdeki tehlikelerin ortaya çıkarılmasında ve risk azaltılmasında Şekil 19'daki standartlar yol gösterici olmaktadır. Makinelerle ilgili direktifler incelendiğinde bazı standartlara atıf yaptığı görülmektedir. Bu standartların emniyetle ilgili olan TS EN 12100'dür.

Ayrıca elektriksel tedbirler açısında TS EN 13849’ dur ve bu standart ile risk kategorisi belirlenir. Belirlenen tehlikeler mekanik ve elektriksel malzemeler kullanılarak tehlikeli durum ortadan kaldırılır. Diğer standart işlevsel güvenlik (elektrikli, elektronik ve programlanabilir elektronik 
sistemler) içerikli TS EN 61508'dir[12] .

Makinelerde risk değerlendirmesi çalışmalarında kullanılacak en önemli araç, TS EN 12100 Makinelerde Risk Değerlendirmesi Standardıdır. Makine Emniyeti Direktifinnin temelini de bu standart oluşturur. Ayrıca bu standardın TS EN 12100'e göre risk değerlendirmesinde hedefler şöyle sayılabilir:

- Riski azaltmak veya ortadan kaldırmak,

- Uygun güvenlik seviyesini seçmek,

- Çalışanın korunmasını sağlamak.

Şekil 19: TS EN 12100 risk azaltma adımları[13]

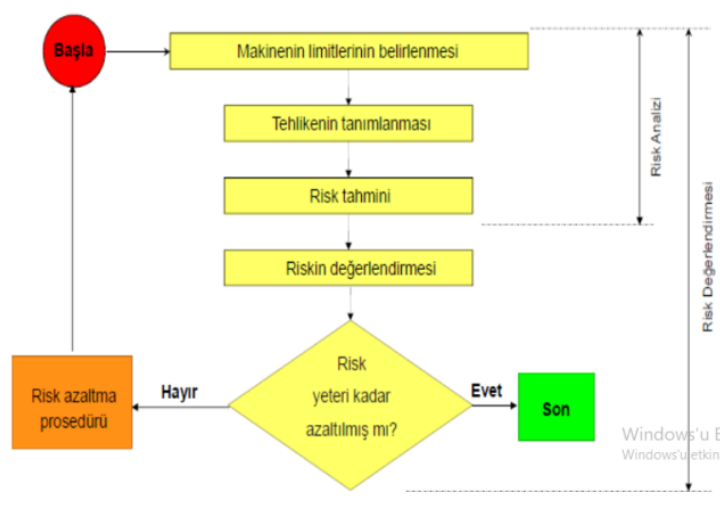

TS EN 13849 harmonize standardın Şekil 20'de Risk Graf uygulaması aşağıda verilmiştir:

S Kazanın sonucu

S1 Hafif yaralanma

S2 Ciddi yaralanma, kalıcı sakatlık veya ölüm

F Tehlike bölgesinde bulunma

F1 Nadiren veya kısa sürelerle sık sık

F2 S1k s1k sürekli veya uzun süreli

P Tehlikenin önlenme olasılığ

P1 Belli durumlarda mümkün

P2 Fiilen mümkün değil
Şekil 20: Risk graf yöntemi ile performansı ve kategori[14]

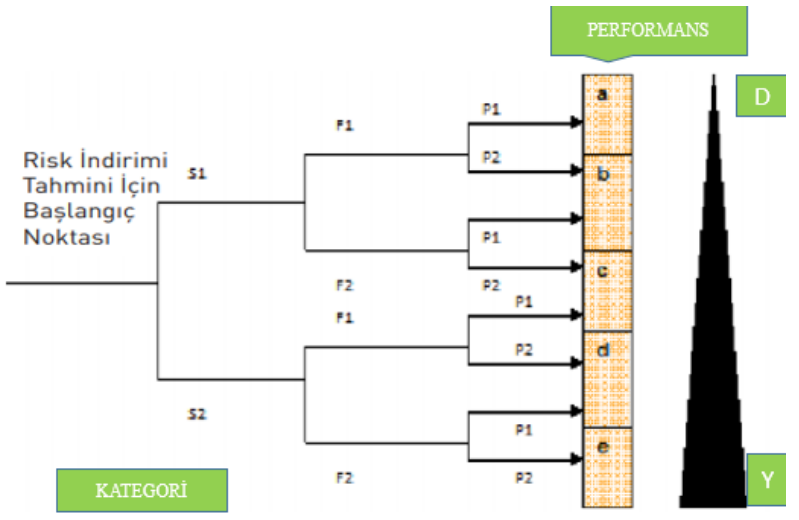

\section{Örnek Siviç Uygulamasının MORD Sonucu}

$\mathrm{Bu}$ standartları basit cümlelerle bir örnek üzerinden anlatacak olursak; Örnek tehlike; Plastik kırma makinesinde elle beleme yapılırken Şekil 21'deki (6) numaralı gövde üst kapağının açılması sonucunda dönen rotorun yaratacağı yaralanma veya ölüm tehlikesidir. Üst kapağın açılma sebeplerine bakıldığında; çalışanın makineyi fazla beslemesi (fazla besleme yapıldığını bildiren ikaz lambası olmadığı durumlarda) durumunda, diğer bir sebep makine çalışır durumda iken kesici kısmı olan rotor üzerinde bağlı kesici bıçaklara termoplastik dışı malzeme atılması sonucunda kırılan bıçakların kırılarak üst kapağı zorlaması veya yerinde firlamasidır.

TS EN 12100'e Plastik Kırma makinesinin çalışır durumda iken üst gövdenin açılma tehlikesidir. Çözüm TS EN 13849'a göre risk azaltılması için siviç kullanılma uygulamasıdır. TS EN 13849’a göre riskin azaltılması siviç kullanılarak yapılmıştır. Şekil 21' de siviç uygulaması görülmektedir. Çalışanın güvenlik fonksiyonu siviç uygulaması ile elektriksel tedbirler kapsamında gerçekleştirilmiştir. Ayrıca risk graf yöntemi ile risk performansı belirlenmiştir. Bu tehlikenin (kapak açılmasının) bertaraf edilmesi TS EN 61508'e göre de siviç uygulamasını elektrik/ elektronik veya programlanabilir elektronik sistem kullanı- 
larak kontrol altına alınabilir.

Şekil 21: Üst gövde siviç uygulaması

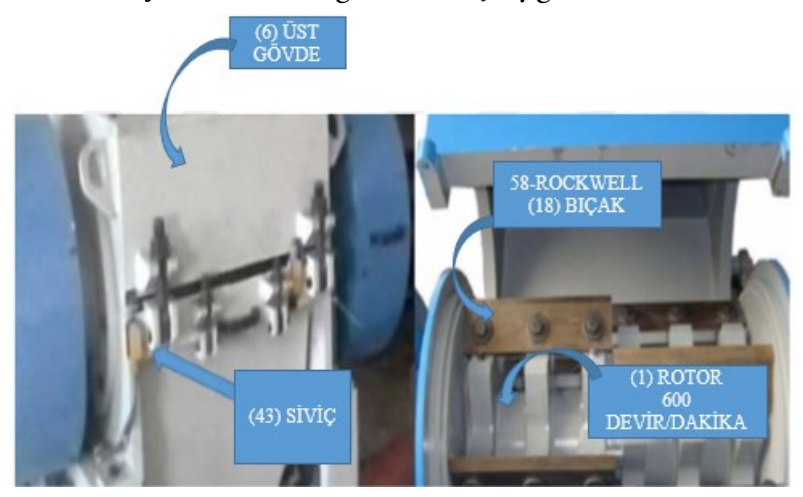

Yukarıda verilen örnekte ve Şekil 19'de TS EN 13849'a göre elektriksel güvenlik için ekipman olarak Şekil 21'de görülen siviç (43) kullanılmış ve tehlike minimize edilmiştir. Ayrıca bu kullanılan siviç körelmiş kesici bıçakların (18) değişimi sırasında, üst kapağın (6) açılması ile rotora (1) aktarım yapan Şekil 11b'de görülen (10) numaralı elektrik motorunun elektrik akımı keserek bıçak değişimi sırasında rotorun hareket geçme olasılığını ortadan kaldırmaktadır. Tablo 13'de MORD bakış açısı, HRNS metodu ve standartları ışı̆ında ayrıca OMGO skalasının en olumsuz şartları göz önünde bulundurularak değerlendirme yapılmışır. Örnek verilen olayda siviç kullanılmaması risk sonucunun 1125 çıkmasına tam tersi siviç kullanıldı̆̆ında ise risk sonucunun 0,25 gibi bir değere düştüğü görülmektedir. Aslında 1125' den 0,25 düşmüş olan sayısal verileri bir tarafa bırakalım; bu olayın söyle bir değerlendirme yapıldığında çalışanın ne kadar etkileneceğine bakalım. Bu olayda değişmezler RAKKS ve TBBS’nin değeri bu olaya göre kesinlikle değişmeyecektir. OYŞ (8-15) aralığında olacağı öngörülmektedir. Bu veriler ışığında OMGO skalasının 15 yani kesin olacakmış gibi insiyatif almak akılcı bir yaklaşım olacaktır. Tablo 13'de siviçin kullanılması gerektiği aksi takdirde sonuçların üzücü olacağı ortaya çıkmaktadir.
Tablo 13: Tehlike derecelendirme numarası sistemi - HRNS

\begin{tabular}{cccccc}
\hline HRNS & RAKKS & TBBS & OMGO & OYŞ & $\begin{array}{c}\text { ILK } \\
\text { TDNS }\end{array}$ \\
\hline $\begin{array}{c}\text { Siviç } \\
\text { Yok }\end{array}$ & 1 & 5 & 15 & 15 & 1125 \\
\hline HRNS & RAKKS & TBBS & OMGO & OYŞ & $\begin{array}{c}\text { SON } \\
\text { TDNS }\end{array}$ \\
\hline $\begin{array}{c}\text { Siviç } \\
\text { Var }\end{array}$ & 1 & 0,5 & 1 & 0,5 & 0,25 \\
\hline
\end{tabular}

Makinelerde kaza olaylarında sorumluluk paylaşımının sınır oranları (\%0-100) Şekil 22'de paylaşılmıştır.

Şekil 22: Makine kaza sonrası sorumluluk paylaşımı[13]

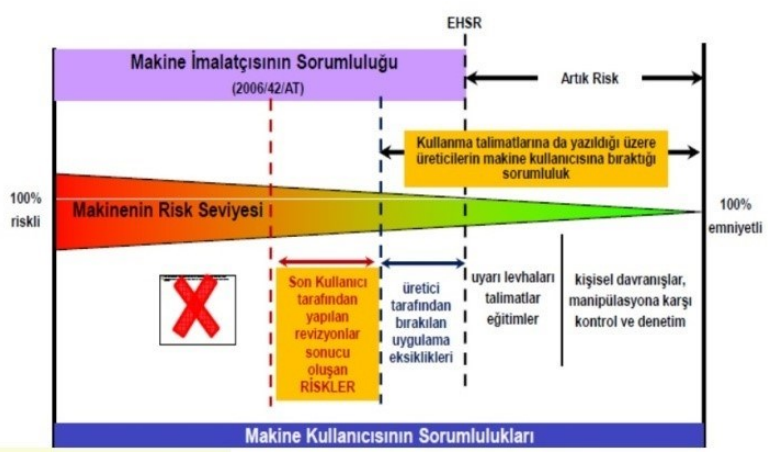

Makinelerde ve süreçte risk fonksiyonlarının azaltılmasinda kanun ve direktifler kılavuz görevi görmektedir. Avrupa'da ve Türkiye'de birbirinin karşllı̆̆ olan kanun ve direktifler incelendiğinde Türkiye'de Makine Emniyet Yönetmeliği'nin Avrupa Birliğini 2006/42/EC sayllı Direktifine paralel olarak hazırlandığı görülebilir.

\section{SONUÇ VE ÖNERİLER}

Türkiye'de her geçen gün plastik geri dönüşüm sektörünün önemi hem çevreye hem ekonomiye pozitif katkı sağlamasından dolayı her kesim tarafından destek görmektedir. Atık plastiğin geri dönüştürüldüğünde ekonomik değer ifade etmesi, toplanıp geri kazanıldığında doğal çevrenin (şehirler, denizler ve ormanlar vb.) temizlenmesine [15] katkısı sağlaması sektörün önemi her geçen gün artmaktadır. 
Plastiği atık kimlerin topladığına bakıldığında; sokak toplayıcıları (bütün atıkları toplayan 500 bin kişi), küçük ve orta boy işletmeler (bütün atıkları toplayan bir milyon işletme), vakıflar ve belediyeler olduğu görülmektedir[16] .

Atık plastiklerin toplanması ile ilgili kurallar ve şartlar sağlandığında geri dönüşüm işletmelerinin kapasitelerini artırarak daha verimli çalışır hale gelecektir. Her geçen yıl geri dönüşüm tesislerinin sayıları artmasına rağmen atık plastiklerin kimin toplaması ortada olmasına rağmen yeterli toplanama yapılamamasından dolayı büyük kayıplar devam etmektedir. Bu durum sektör paydaşlarının önünün açılmasında en önemli sorun olarak durmaktadır. Çevre kirliliğini önemli oranda azaltmak, istihdama katkı sağlamak ve kayıt dışılığı en aza indirmek için çalışmalar daha verimli hale getirilebilir.

Örnek bir proje anlatacak olursak; sokaktaki atık plastik toplayıcılarından (tüm atık metal, plastik vb - toplayıcı 500 bin kişi) bir kısmına başlangıç olarak pilot ilçelerde seçilecek sanayi sitelerinde belirli alanlarda küçük ölçekli işletmeler kurdurulmalıdır. Bu işyerlerinde kurulacak kırma ve yıkama havuz süreci (plastik çapak üretimi ile kısıtlı) oluşturulması yerel belediyelerin desteğinde ve kontrolünde olmadır. Ayrıca bu işletmeler büyük ölçekli tesislere entegre edilmelidir. Bu gibi projelere plastiğin yarattığı çevre kirliliğinin ortadan kaldırılmasına, istihdama ve ekonomiye katkı yapacağı açıktır.

Atık plastiklerin ekonomiye kazandırmasında dönüşümün yapıldığı makine süreçte uygulama sırasına göre; hidrolik presler, giyotin makas, seperatör elek, (kompozit yapılı plastiklerde kullanılır) şerit testere, taşıyıcı bant, plastik kırma makinesi, taşıyıcı helezon, yıkama havuzu, Sıkma makinesi, agromel makinesi, extruder makinesi, kafadan kesme ekipmanı, iletici fanı ve depolama haznesi gibi makineler kullanılır. Türkiye’de plastik geri dönüşüm sektörün- de lisanslı işletme sayısı 1039 bu işletmelerde azami 350 bin kişi istihdam edilmektedir. Bugün itibariyle kapasite olarak 850 bin tona ulaşmıştır. 2030 yılında normal gidişat ile 4,3 milyon ton hedefte durmaktadır. Plastik geri dönüşüm sektörü 2018 y1l 436 bin ton hurda atık plastik ithalatı yapmış 116 milyon \$ ödemiştir. Bu atık plastik işlemlerden geçerek plastik mamul haline getirilerek 770 milyon \$ a ihracatı gerçekleştirilmiştir. Ayrıca; plastik ambalaj sektöründe 1450 firma faaliyet içindedir. Yapılan malzeme bazındaki üretimler belirli bir birim üzerinden tarifi yapılmamaktadır. Sektördeki üretim dağılımı ise \% 67'si fleksible plastik, \% 18'i tekstil plastik ve \% 15'i de sert plastik ambalaj malzemelerinden oluşmaktadır[7]. Ayrıca bu firmaların illere göre dağılımı Tablo 2'de verilmiştir.

Gövde genişliği 200-400 mm (taşıyıcı bant sistemi olmayanlar) plastik kırma makineleri plastik ürün üreten işletmelerde üretim zayiatı ve basılan ürünün kalıptaki yolluk kısımlarının tekrar geri dönüştürülmesinde kullanılır. Plastik kırma işlemi gövde genişliği 500-1500 mm olan makinelerde kesinlikle taşıyıcı bant sistemi olmadan çalışma yapılmamalıdır. Taşıyıcı bant sistemi olmadan, elle çalışma yapılması uzuv kayıplarının ve ölümlü kazaların önünü açmaya devam edecektir. Yapılan iki farklı risk değerlendirmesinde, olayın meydana gelme sıklığının düşük olması nedeniyle olasılık faktörünün düşük tutulmasının objektif bir yaklaşım olmayacağı gibi, risk sonuçlarının da doğru çıkmayacağı açıktır.

Bu çalışmada iki farklı PHA ve HRNS metotları ile karşılaştırmalı olarak risk değerlendirmesi yapılmıştır. Örnek tehlike olarak seçilen, plastik kırma makinesinde üst gövde (6) kapağının açılması tehlikesinin önlenmesine yönelik siviç uygulamasını MORD bakış açısı, HRNS metodu ve standartları ışığında, OMGO skalasının en olumsuz şartları göz önünde bulundurularak değerlendirmesi yapılmıştır. Ayrıca plastik geri dönüşüm sektörü ve 
plastik mamul üretimi sektörü de kullanılan makinelerde tasarım, kullanım ve bakımdan kaynaklı tespit edilen beş tehlikenin risk değerlendirmesi yapılmıştır. Bu çalışmada işlediğimiz beş tehlikenin en önemlisi kırma makinelerinde elle besleme tehlikesidir. Bu tehlikenin olasılık skalasının düşük olması, farklı metotlar kullanıldığında tehlikenin önemsenmemesine neden olmaktadır. İşte böyle bir olayın meydana geldiği andan itibaren şiddetinin ortaya koyduğu katlanılamaz durum bize şunu söylemektedir. Bir olayda ortaya çıkacak sonuç katlanılmaz acılara neden olacak ise olasılık skalasının en yüksekten algılanması akılcı bir yaklaşım olacaktır. MORD'da kullanılan; HRNS metodu makinelerde meydana gelebilecek tehlikeli olayların proaktif yaklaşım ile değerlendirmelere uygun, akılcı ve pratik metot olduğu yapılan çalışmamızda görülmüştür.

\section{KAYNAKLAR}

[1] PAGEV, (2018). Türkiye Plastik Sektör İzleme Raporu

[2] Brydson, J. A. (1999). Plastics materials. Elsevier.

[3] Crawford, R. J. (1998). Plastics engineering. Elsevier.

[4] Thompson, R. C.,Moore, C. J., VomSaal, F. S., \&Swan, S. H. (2009). Plastics, the environment and human health: current consensus and future trends. PhilosophicalTransactions of the RoyalSociety B: Biological Sciences, 364(1526), 2153-2166.

[5] Law, K. L. (2017). Plastics in the marine environment. Annual review of marine science, 9, 205-229.

[6] Yalman, N., Erdim, K., Akata, E.H., (2018). "Polimer Malzemelerin Geri Dönüşüme Kazandırılması İçin Plastik Kırma Makinesi Tasarımı ve İmalat1" ENAR 2018 Proceedings Book International Congress on Engineering and Architecture 237-243.

[7] PAGEV, (2019). Türkiye Plastik Sektör İzleme Raporu

[8] Yalman, M. M. N.,\&Akata, H. E. (2019). Atık Plastiklerin Geri Dönüşümle Sanayiye Kazandırılmasında Kullanılan Plastik Kırma Makinelerinde Karşılaşılan
Riskler ve Çözüm Önerileri. Cataloging-InPublication Data, 586.

[9] Pierson, L. A.,Davis, S. A., \& Van Vickle, R. (1990). Rockfall hazard ratings ystem: implementation manual (No. FHWA-OR-EG-90-01).

[10] Yalman.N., (2019) "Plastik Geri Dönüşüm Sektöründe Kullanılan Makinelerde Karşılaşılan Risklerin İncelenmesi”, İstanbul Aydın Üniversitesi, Fen Bilimleri Enstitüsü, Yüksek lisans Tez Çalışması, İstanbul.

[11] Rausand, M. (2005). Preliminary hazard analysis. Norwegian University of Science and Technology.

[12] Özkılıç, Ö. (2008). İş Sağglğı ve Güvenliğinde Risk Değerlendirmesi, 5. İş Sağlığı ve Güvenliği Dergisi, (40).

[13] Türer, N., (2013). "Ce, Makine Emniyeti ve Risk Değerlendirmesi” İSG Haftası Seminerleri, MESS Metal Sanayicileri Sendikası 1-94

[14] Özkılıç, Ö., 2016. Makine Risk Değerlendirmesi, Önder Akademi, http://www.onderakademi.com/ blog/isg-dergi-makaleler/makine-riskdegerlendirmesi.pdf, (Erişme Tarihi: 22.12.2017)

[15] Alam, O., Billah, M., \&Yajie, D. (2018). Characteristics of plastic bags and their potential environmental hazards. Resources, Conservation and Recycling, 132, 121-129.

[16] Yetim, A., (2014). "Geri Dönüşüm Sektöründe Dünyadaki Genel Görünümü ve Türkiye’deki Durumu”, İzto Ar-Ge Bülteni, 11-1. 